\title{
Older People in a Long-term Regeneration Neighbourhood. An Exploratory Panel Study of Ageing in Place in Hoogvliet, Rotterdam
}

\author{
Reinout Kleinhans ${ }^{1, *}$, Lex Veldboer ${ }^{2}$, Maarten van Ham ${ }^{1,3}$, Sylvia Jansen ${ }^{1}$ \\ ${ }^{1}$ Department OTB-Research for the Built Environment, Faculty of Architecture and the Built Environment, \\ Delft University of Technology, Netherlands \\ ${ }^{2}$ Amsterdam Knowledge Centre for Societal Innovation, Faculty of Applied Social Sciences and Law, \\ Amsterdam University of Applied Sciences, Netherlands \\ ${ }^{3}$ Department of Geography \& Sustainable Development, School of Geography and Geosciences, University of St Andrews, UK
}

Copyright $\bigcirc 2018$ by authors, all rights reserved. Authors agree that this article remains permanently open access under the terms of the Creative Commons Attribution License 4.0 International License

\begin{abstract}
Ageing of the population in European cities creates fundamental challenges with regard to employment, pensions, health care and other age-related services. Many older people want to live independent lives as long as possible. This aspiration is currently strongly supported by many local governments. A precondition for 'ageing in place' is that older people perceive their neighbourhoods as familiar and safe places. In the Netherlands, many neighbourhoods with an ageing population have been subject to urban restructuring policies. An important question is to what extent such policies affect the housing situation, socioeconomic position and social support networks of older people, as these factors strongly assist their ability to 'age in place'. The paper answers this question through an exploratory analysis of a small but unique panel data set from Hoogvliet, a large urban restructuring area in the city of Rotterdam. The partly counter-intuitive results show that restructuring has enabled 'ageing in place'. Compared to stayers, movers within Hoogvliet often report improved housing quality and positive neighbourhood change. The exploratory analyses did not provide evidence of decreased social support or increased loneliness through restructuring-induced disruptions of social ties. Various 'buffer measures' have been effective in preventing negative restructuring impacts on older residents.
\end{abstract}

Keywords Ageing in Place, Urban Restructuring, Social Networks, Social Support, Loneliness, Rotterdam

\section{Introduction}

An important demographic development is the ageing of the population in many countries [1]. The growing shares of older people raise huge societal challenges with regard to the labour force and funding of pensions, health care and other age-related services [2]. Ageing does not only raise macro-level economic issues. On city and neighbourhood level, policymakers grapple with the question how to accommodate ageing in the (re)development of urban neighbourhoods. For example, many Dutch local governments have implemented policies that support older people to remain in their current dwelling instead of 'moving' them into old people's homes or nursing homes $[3,4]$. Such 'ageing in place' policies are not only considered as necessary for cutting the costs of institutionalized care, but also expected to have positive implications for the physical and mental health and well-being of older people $[1,5,6]$.

A precondition for the success of such policies is that older people feel safe in their homes and that they perceive their neighbourhoods as familiar, safe, clean and healthy places to grow old [6-9]. Creating 'age-friendly' neighbourhoods or even cities is a huge challenge [10-12]. Many less affluent older people live in deprived neighbourhoods where low-quality housing, crime, disorder and tensions between ethnic groups, have decreased the liveability of such areas [7, 13]. Many of those neighbourhoods in Western European countries have been subject to intensive urban restructuring policies. While urban restructuring includes social and economic interventions, a key element across Europe is demolition of cheap social rented housing, new construction of more expensive rental or owner-occupied housing, and renovation of infrastructures and public space. The Netherlands are a prime example, featuring a national urban restructuring programme (Stedelijke Vernieuwing) that focussed on the social housing stock of early post-war 
neighbourhoods. The relocation of tenants from dwellings slated for demolition has been a most controversial element in this programme.

Many urban restructuring studies which focus on general populations remaining in target areas (see e.g. [14]) have not specifically targeted older people. The same applies to literature reviews of health impacts of housing improvement or wider urban restructuring efforts (for an overview, see [15]). Van der Meer et al. [13] have called for more research into the impacts of neighbourhood transitions on the well-being of vulnerable older adults. Existing research primarily deals with older people's sense of belonging and place attachment, and with the (potential) 'damage' done by regeneration in this respect [16-18]. On the one hand, older people can be adversely affected by rapid changes in the physical fabric and service structure in neighbourhoods and high residential turnover, resulting in disruption of supportive relationships that also have a potential to prevent loneliness $[19,20]$. On the other hand, urban restructuring may cater for residential environments that facilitate ties between older people and supportive network members, and integrate new housing solutions that accommodate (care) needs and thus enable 'ageing in place' [6, 7, 10-12].

Except for qualitative research including multiple contacts with research subjects spanning eight months [9] or several years [21], many existing studies of ageing in place are cross-sectional and unable to detect changes over time. However, loneliness and a lack of social support may develop over time in either positive or negative ways. Furthermore, the available research does hardly distinguish between older residents who were differently affected by various types of key interventions in the context of urban restructuring. While some older residents stay put in the same dwelling, others may have to move because of demolition, or they voluntarily move into newly constructed dwellings within the restructuring area (see also $[15,17])$. This will likely have varying impacts on perceived restructuring benefits or burdens, such as housing satisfaction and mental health.

Considering these caveats, this paper aims to establish medium term impacts of typical restructuring interventions on the housing situation and social support networks of older people in a long-standing urban restructuring area in Rotterdam. This area, called Hoogvliet, is a borough at the southwestern edge of the city of Rotterdam. It has been subject to the third largest urban restructuring operation in the Netherlands and is also one of the very few areas in which restructuring impacts have been studied with multiple measurements over time [22]. Our research question is threefold:

1. How do the housing characteristics of older residents in the restructuring area change over time?

2. To what extent do differences in perceived housing and neighbourhood benefits occur between stayers and movers to other dwellings in restructuring areas?

3. To what extent has restructuring affected loneliness and perceived social support among older residents?

We will answer these questions through the analysis of a small but unique panel data set of 160 older residents living in Hoogvliet. Despite its limitations (section 3), this panel data set enabled us to provide exploratory analyses of changes on a limited but important range of socioeconomic, housing, neighbourhood and social network indicators. Before we describe the data, methods and results, we review the academic literature that is relevant for our research questions.

\section{Literature Review}

With urban regeneration policies now being in force for decades, the body of research dealing with various impacts of regeneration and renewal measures is growing steadily, particularly in the United States and the United Kingdom. Particular subjects of attention are physical and mental health impacts of housing improvement or wider area-based regeneration efforts. This is a field of study in which many systematic reviews are available [23-26]. While there is some evidence that housing improvement can improve general, mental and respiratory health, Egan and colleagues [15] have observed that the evidence base is neither comprehensive nor conclusive, particularly regarding neighbourhood-level renewal. They also observe that reviews have reported some evidence that such interventions may have unintended consequences. Moreover, the evidence reviews target general populations and not older people in particular, which makes it particularly difficult to 'filter out' regeneration outcomes for older people. Regardless of positive outcomes, the process of restructuring itself may have adverse impacts. Especially large-scale demolition, vacant dwellings, closing of neighbourhood amenities, the disruption of new construction activities and lack of progress may create frustration, uncertainty and prolonged exposure to deteriorating environmental conditions [27, 28], which may in turn negatively affect mental health, especially of older people.

Another well-documented strand of research investigates the extent to which urban restructuring affects older people's sense of belonging and place attachment [16, 29-31]. These studies have revealed a range of complexities that older people have to cope with, and often point at deleterious effects of urban restructuring on older people's place attachment, either as a result of forced moves or due to significant changes in the familiar living environment of older people. A useful concept has been offered by Rowles and Watkins [32], who discuss the notion of older adults 'being in place'. 
This is described as a feeling of being comfortable at home and comfortable with one's environment. The work of Rowles and Watkins [32] offers a life course approach that is very useful to emphasise the importance of place-making and meaning-making skills developed and accumulated over the life course. These skills help older people to cope with environmental changes in later life $[21,33]$. Older adults can become 'out of place' and feel less comfortable in their living environment after changes in their personal situation or during and after radical changes in environment itself. If we translate this to the context of urban restructuring, it is clear that radical changes in terms of housing stock, public space and services can make people lose their trusted environment $[5,13,21,27]$. According to Jones and Evans [34], policy rhetoric on the importance of sense of place in regeneration often reveals a sharp contradiction with outputs of regeneration schemes that deliberately 'erase' residents' affective connections with place.

On both sides of the Atlantic, a range of studies has focussed on demolition of public or social housing and the related forced relocation of tenants. These studies have paid due attention to experiences of older people with the relocation process, explaining social and institutional mechanisms, people's lack of agency, feelings of displacement, disruption of social networks and often eroded well-being [7, 17, 18, 27-29, 35-37]. This branch of studies seems to dominate the debate on the presumably unfavourable position of older people in urban restructuring. This framing occurs despite some evidence of compensation and positive outcomes for older people's housing situation, especially when they were able to move to new (senior) housing at reduced social rents within or close to the restructuring area [38, 39]. Other research has also shown that older people express a strong attachment to their ability to make decisions about where to live, rather than someone telling them to move because of various reasons [33, 40]. In fact, a study in the UK has revealed that many older people who are dissatisfied with their houses as they age, are very pleased to move [41].

Many of the aforementioned issues, in particular neighbourhood-induced changes in people's sense of belonging and disruptions of social networks, can affect loneliness among ageing people. Scharf and De Jong Gierveld [19] identify at least three interrelated processes that are relevant for the context of urban restructuring. First, older people can be adversely affected by changes in the physical fabric of cities and neighbourhoods. It is obvious that radical changes in the housing stock and forced relocation may disrupt the types of social relationships that may prevent loneliness. Second, older people's social well-being is prone to rapid changes in population composition; these changes result in people losing 'familiar faces' in the neighbourhood, which were important not only in practical terms, but also to their sense of place (see also [31]). Hence, they may feel increasingly like a stranger in their own neighbourhood, as high residential turnover is a key feature of areas undergoing intensive restructuring. Thirdly, restructuring-related changes in service infrastructure and local shops and the related loss of familiar meeting places may increase reluctance among older people to go out on the street to meet friends or acquaintances (see also [40]), thus increasing the risk of loneliness. This is connected to health and well-being, as social isolation and loneliness tend to exacerbate personal care needs, whereas socially-included individuals are more likely to participate in the activities that help promote active ageing and reduce care needs [3].

According to many scholars, local communities should form a supportive environment for older people [16, 20], but this does not come easily. Comparative research has shown that older people see 'healthy' ageing as an active achievement that must be created through personal effort and supportive ties that enable them coping with the physical and mental challenges associated with old age [20]. Maintaining social ties, not only with family and friends but also 'meaningful others' within the neighbourhood is crucial to mobilise practical and social support, and preventing loneliness $[9,40]$. In fact, much social support is often provided by older people themselves. A study of an English deprived community revealed a significant share of older adults among volunteers for organizations providing social welfare services for people (i.e. non-household members) in this community [42]. The mentioned impacts of urban restructuring on social networks and loneliness are also linked to social support. In a longitudinal study of 15 deprived neighbourhoods in Glasgow, Kearns and colleagues [43] found that the absence of practical support is associated with frequent loneliness.

A final important factor to consider is that the recent economic crisis has delayed, slimmed down or cut restructuring policies as part of government austerity programs, also in the Netherlands. Apart from downsizing and decreasing potentially beneficial interventions, the crisis may also have offset hard-fought restructuring program benefits [14], for example by laying off people who were helped into paid employment, or local support programs for older residents. Macro-economic implications of the economic crisis include increasing the cost of living for older people by lowering housing and health care allowances and not indexing their pensions. Subsequently, older people may have fewer opportunities to visit family or friends and to participate in leisure activities or voluntary associations, thus further increasing (the risk of) social isolation. The combination of macro-economic developments and terminated policy programs emphasizes the need to look at how restructuring benefits have developed from the situation before the crisis to its culmination around 2011/2012. 
Based on this literature review, we seek to analyse the following matters: 1) changes in the housing situation of older residents; 2) differences in perceived housing and neighbourhood benefits among stayers versus movers to other dwellings in the restructuring area, and 3) changes in loneliness and perceived social support for older residents.

\section{Materials and Methods}

\subsection{Research Area}

The Dutch city of Rotterdam expanded rapidly after the Second World War, largely due to housing shortages caused by war damage. Hoogvliet, a borough in the south-western part of the city, was built mainly during the 1960s and was created to house employees of the nearby petrochemical industry. A large part of the housing stock consisted of four- to six-storey apartments in the social rented sector, with significant public spaces between blocks. In the following decades, economic recessions and restructuring adversely affected the industry and unemployment rose rapidly. Early in the 1990s, the district authorities launched a social regeneration policy to reverse the decline of Hoogvliet. This social approach paved the way for a large-scale housing restructuring project that started in 1999 and was completed in 2015. The project has transformed the housing stock of five neighbourhoods surrounding the central area of Hoogvliet (see Figure 1) by demolishing 5,000 social rented dwellings and replacing them with more expensive rental and owner-occupied properties, and selling off 1,500 social rented dwellings [44]. The key principles of the renewal were framed in terms of improving the housing stock, local economy, public space, and reputation, and in particular improvement of the residents' social economic position [44]. A unique feature of this restructuring project is a fundamental promise made by the borough authorities and local housing associations to the residents. This promise implied that anyone who was obliged to move because of demolition had the right to return in the same restructuring area or another restructuring neighbourhood in Hoogvliet [45].

Here, we will only discuss interventions that directly affected older people in the restructuring areas. Analysis of the strategic plan underlying the large-scale restructuring that started in 1999, reveals that the local government and housing associations were keen on minimizing the potential negative impacts of the restructuring on the well-being of older people [45]. First of all, older residents who were relocated to other social housing not only received a formal compensation for moving costs (see [38, 39]), but also received discounts on standard rents that would be charged to new residents from outside Hoogvliet. This strategy aimed to increase the affordability of new dwellings and to minimize financial stress for older movers. Secondly, all new constructed housing, in particular social rented dwellings, was equipped according to legal requirements for senior housing, including elevators, adjusted bathrooms, etc. Thirdly, the aforementioned right to return not only supported older people in the relocation process, but also stimulated some self-organised groups of older residents to become active agents in the restructuring process. These residents wanted to stay together after demolition of their dwellings, joined forces and negotiated an active role in the design of replacement housing, targeting their preferences and future social care needs. This resulted in the development of several co-housing communities where groups of people aged 55 years and older live in houses developed in close co-operation with the housing associations [44].

As part of the range of interventions to strengthen social cohesion, particular attention was devoted to older people facing relocation due to demolition. A so-called 'senior citizens brigade' (seniorenbrigade) was established in which senior citizens were helping each other out with various problems [44]. Another deployed instrument entailed 'neighbourhood houses' (praathuizen), i.e. vacant social rented dwellings accommodated by the housing association to serve as meeting spots for older people, for the time of the construction works. These meeting places were also used by the housing association or local authority councillors to exchange information and provide support in various stages of the restructuring process $[44,45]$. 


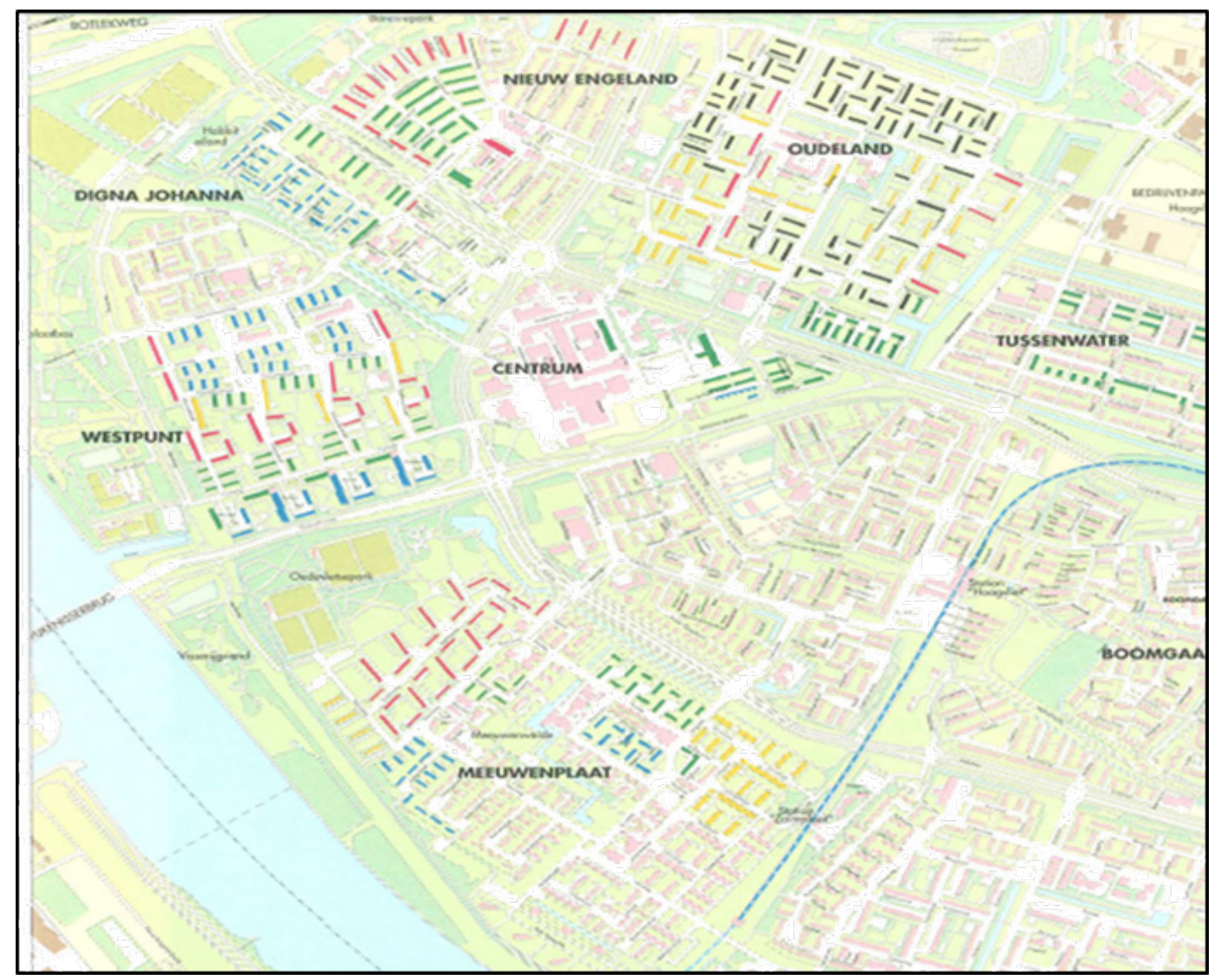

Figure 1. The borough of Hoogvliet [45]. The colours indicate housing blocks slated for demolition (red), sale (blue), or continued rent (green) [45] Housing blocks coloured black were subject to study at the time of the launch of the restructuring plan. Yellow indicates owner-occupied housing.

\subsection{Data and Analysis}

Our primary interest lies with residents who were about to reach the formal Dutch pension age in 2012. Socioeconomic mobility is usually (almost) non-existent among people who have retired and have abandoned paid employment by this age. We are particularly focusing on residents who were approximately 50 years or more when the restructuring started in 1999, and who now have reached the age of 63 and older. While the formal Dutch pension age was 65 years (in 2012), Dutch population statistics show that by the age of 63, only a small fraction is still active in paid employment, while the majority has retired. Hence, we will use this cut-off.

We use a panel dataset based on large surveys conducted in 2007 and 2012, as part of a longitudinal research project on the outcomes of urban restructuring in Hoogvliet. This approach is a response to the observation made by several scholars, i.e. that panel surveys to assess impacts on the original residents in the context or area-based initiatives are rare $[14,24]$. In 2007, we completed a mixed-methods study of experiences of long-term stayers and movers, within Hoogvliet, i.e. all residents who remained in the Hoogvliet district during the period 1999-2007 [46]. Lacking a proper baseline measurement in 1999, this particular study used a retrospective survey to reveal changes in a set of neighbourhood and individual indicators that may have been affected by various restructuring measures, such as housing and neighbourhood satisfaction, social and physical disorder, and social cohesion. The research population consisted of approximately 6,000 households, of which almost 19 per cent $(n= \pm 1,140)$ were seniors of 63 years and older (according to the Municipal Base Administration of 2006). The survey questionnaires were distributed by postal mail and could also be returned through postal mail with stamped envelopes. We also deployed research assistants to ring at the doors of people who were part of the research population, to collect completed surveys. This approach yielded a response of 1,684 ( 25 per cent) usable questionnaires, of which half ( $\mathrm{n}$ $=841$ ) were returned by respondents who were 63 or older. In other words, older people were strongly overrepresented in the response, while non-response analysis (not shown here) has revealed that ethnic minorities were slightly underrepresented [46]. For the purposes of our paper, the outcome of a strong overrepresentation of older people (i.e. 841 out of approximately 1,140 ) was useful for increasing the potential size of a panel of older residents. We cannot ascertain to what extent the response is representative for the larger population. However, in line with the exploratory nature of this panel study, we were mostly concerned with exploring medium term impacts of typical 
restructuring interventions on the housing situation and social support networks of older people. For this reason, we asked respondents from the 2007 survey for their consent to contact them for subsequent research and to establish a panel that would enable us to achieve this aim.

In 2012, we set out a much larger survey for a follow-up study with a wider scope, i.e. also including residents who had moved into the Hoogvliet district from other parts of Rotterdam or beyond [22]. We used a similar strategy as in 2007 , by distributing survey questionnaires by postal mail, adding stamped return envelopes and have research assistants ring at the doors to collect completed surveys. This survey was predominantly based upon a random sample of adult residents in Hoogvliet but also on a population administration data check of respondents of the 2007 survey, in order to approach them again for the follow-up survey. As a result of missing address data, residential mobility, deaths and other life cycle events, only a quarter of the respondents from 2007 could be retraced in 2012. This yielded a panel of 160 respondents aged 63 years or older who were interviewed in both years. Their common characteristic is that they have lived in Hoogvliet since the start of the restructuring project in 1999 and have lived in the same dwelling since then (stayers) or have moved to another dwelling within the same or another restructuring area (movers) in Hoogvliet. In other words, this panel has been fully exposed to restructuring from the very beginning. Appendix A lists the demographic characteristics of the respondents. Two-thirds are men, one third are women. Almost half of the respondents are aged 63-74 years and 44 per cent are aged 75-84 years. In terms of household composition, 36 per cent are single and 56 are couples without children living at home. And 90 per cent are native Dutch; the remainder have a background mostly in Surinam or Indonesia.

We focus our analysis on changes in housing situation, and indicators of social support and loneliness. Interestingly, the timing of the measurements allows an indication of the extent to which the economic crisis has affected this group.

The first measurement (2007) was conducted before the start of the economic crisis (early 2009), while the second measurement coincides with its peak (2012), at least in public perception. Because our assessment is based on change for individuals, analyses will automatically control for fixed person specific latent characteristics, such as a respondents gender or a trait of extraversion, which may influence the propensity to record a given outcome [14]. Unfortunately, we have no control group for this panel, so we cannot establish with full certainty whether the reported changes are the result of restructuring measures or other factors in time. This problem is partly overcome by using survey questions that include direct links between interventions and specific outcomes.

Depending on the nature of the relationships tested and the measurement level of the variables, we have used various statistical methods, including Fischer's Exact test, McNemar change test, Chi-square test, Mann-Whitney test, Wilcoxon Sign Rank test, and Marginal Homogeneity test. In section 4, the main results will be described.

\subsection{Limitations}

There are some limitations to this study. Obviously, the sample size and the specific site characteristics limit the generalizability of findings. The relatively low responses are common among field studies in Dutch restructuring research, and this probably results in selection bias. The loss of respondents between 2007 and 2012 is somewhat larger than could be expected from illness, disability and deaths so we assume that the loss of respondents between two measurements is partly selective. However, it is unlikely that this selection has resulted in overly positive results. In our study [22], we found that many older respondents seized the opportunity offered by the survey to complain about a wide range of issues, both related and unrelated to the local restructuring programme.

Moreover, the design of the study might suggest that we have included relatively young people in our panel, which could result in a disconnection with the literature on ageing in place, which focuses on much older people. Closer inspection of all panel respondent characteristics (see Appendix A) reveal that more than half $(52.5 \%)$ of them are actually 75 years or older. Finally, the research underlying this panel analysis aims to establish the effects of mostly physical restructuring interventions, but not particular social interventions such as the 'senior citizens brigade', counselling and meeting points (see section 3.1). While these interventions may have alleviated negative restructuring impacts, our data do not allow for a proper evaluation of their implications.

\section{Results and Discussion}

\subsection{Changes in the housing situation}

With a few exceptions, all panel respondents are social renters. At first sight, Table 1 may evoke the impression that only very few people moved between $t_{0}$ and $t_{1}$, considering e.g. the smaller number of people living in single-family dwellings at $t_{1}$. Indeed, a small number of respondents have moved from single-family dwellings to independent apartments, special senior housing or an apartment in a co-housing community. These moves appear to reflect the need for adjusting the housing situation to the changing needs of older people, supporting them in their capability of finding ways to maintain their routines and manage themselves in their own dwellings $[33,40]$. However, Table 1 does not reflect that some respondents moved within the same housing type, such as (independent) apartments. 
Table 1. Changes in the housing situation

\begin{tabular}{|c|c|c|c|c|c|c|c|}
\hline \multirow[t]{2}{*}{ Indicator } & \multicolumn{2}{|c|}{$t_{0}(2007)$} & \multicolumn{2}{|c|}{$t_{1}(2012)$} & \multirow[t]{2}{*}{ Test type } & \multirow[t]{2}{*}{ Statistic } & \multirow[t]{2}{*}{ p-value } \\
\hline & $n$ & $\%$ & $n$ & $\%$ & & & \\
\hline \multicolumn{8}{|l|}{ Housing Tenure } \\
\hline - Social rent & 149 & 93.1 & 143 & 89.4 & McNemar Test & N.A.*** & 1.000 \\
\hline - Owner occupation & 7 & 4.4 & 7 & 4.4 & & & \\
\hline - Unknown & 4 & 2.5 & 10 & 6.3 & & & \\
\hline \multicolumn{8}{|l|}{ Housing Type: } \\
\hline - Single-family dwelling & 71 & 44.4 & 62 & 38.8 & Marginal & Std. $\mathrm{MH}=$ & 0.846 \\
\hline - Apartment (independent) & 64 & 40.0 & 67 & 41.9 & Homogeneity & -0.195 & \\
\hline - 'Senior housing' & 15 & 9.4 & 19 & 11.9 & & & \\
\hline - Apartment in CHC\# & 7 & 4.4 & 10 & 6.3 & & & \\
\hline - Other & 3 & 1.9 & 2 & 1.2 & & & \\
\hline
\end{tabular}

Source: panel data extracted from surveys 2007 and 2012. Significant $p$-values ( $\leq \leq 0.05)$ are printed boldly. \# CHC: Co-Housing Community.

*** In some cases, SPSS does not provide a $\chi 2$ test statistic for the McNemar test, but only a p-value. This is because SPSS calculates the p-value differently depending on the number of discordant pairs in the cross table that compares the measurements. If the number of discordant pairs is small, the McNemar test $\chi^{2}$ is not well approximated by the $\chi$-squared distribution. In such cases (a rule of the thumb is N_D $<25$ ) a two-tailed exact test based on a binomial distribution is used by SPSS and no separate test statistic is reported.

\subsection{Attribution of Individual and Neighbourhood Benefits to Restructuring}

In section 3.2, we explained that the $2007\left(\mathrm{t}_{0}\right)$ and 2012 $\left(t_{1}\right)$ questionnaires were only partly identical. This is the result of the differences in focus between the two commissioned studies that are at the basis of our panel [22, 46]. In the 2012 survey, we have asked respondents to reflect upon the extent to which they feel that changes in their own personal situation and in the development of their neighbourhood can be attributed to restructuring, especially demolition of unattractive social housing, new construction of higher-quality social or owner-occupied housing, improvement of public space, and so on - see section 3.1 and [22]. These data are not available for 2007. In order to link panel members' perceptions of restructuring benefits to the actual restructuring interventions, we distinguish between panel members who moved due to the restructuring (movers) and those who remained in the same dwelling between $\mathrm{t}_{0}$ and $\mathrm{t}_{1}$ (stayers). In other words, the first group (movers) was directly affected through a move within the restructuring area, regardless of whether this move was perceived as voluntary or involuntary. Thus, any between-group differences in perceived restructuring benefits are likely to be connected with changes (or a lack thereof) in the housing situation.

In the 2012 survey we asked for the most important reasons underlying the move. For half of the movers, demolition of the previous dwelling was the main trigger. The other half decided to move because of pull factors (availability of new housing close by) or push factors (dissatisfaction with the previous dwelling). All of them moved within the same restructuring area or to one of the other four restructuring areas in Hoogvliet (see Figure 1).

Table 2 shows that stayers more often live in a single-family dwelling, while movers significantly more often reside in a (new) independent apartment, housing tailored to older people's needs, or an apartment in a co-housing community. Not surprisingly, almost all stayers reported no changes in the housing situation. This applies to almost one third of the movers. More than 60 per cent of the movers report a personal benefit from restructuring, compared to only a quarter among the stayers. 'Personal benefit' refers to positive outcomes in the personal or housing situation which is directly linked to any restructuring intervention. Other 2012 survey data (not reported here) show that these personal benefits are associated with changes in the housing situation, i.e. higher overall dwelling quality, insulation, better kitchen and bathrooms, and more space [22].

Likewise, movers are significantly more often positive than stayers about changes in their current neighbourhood. Whereas 43 per cent of the movers feel that their neighbourhood has improved, the share of stayers reporting this outcome is about half this share ( 22 per cent).

Whereas 28 per cent of the stayers reports 'decline', only five per cent of the movers has reported the same perception. We found that this difference can be partly explained by movers' transition to new constructed dwellings in their own neighbourhood or other restructuring areas in Hoogvliet (see Figure 1). Almost 60 per cent of the movers ascribed the perceived neighbourhood change (or stability) partly or completely to the restructuring. The share of stayers reporting this outcome amounts to 43 per cent. The finding that housing renewal drives neighbourhood satisfaction is in line with other research in the Netherlands [38, 39, 47] and in the United Kingdom [27]. Further analyses (not shown here) indicate that there are no stayers who attribute perceived neighbourhood decline to restructuring efforts [22]. 
Table 2. Stayers versus movers in 2012

\begin{tabular}{|c|c|c|c|c|c|c|c|}
\hline \multirow[t]{2}{*}{ Indicator } & \multicolumn{2}{|c|}{ Movers $(n=39)$} & \multicolumn{2}{|c|}{ Stayers $(n=119)$} & \multirow[t]{2}{*}{ Test type } & \multirow[t]{2}{*}{ Statistic } & \multirow[t]{2}{*}{ p-value } \\
\hline & $n$ & $\%$ & $n$ & $\%$ & & & \\
\hline \multicolumn{8}{|l|}{ Housing Type: } \\
\hline - Single-family dwelling & 2 & 5.1 & 59 & 50.0 & Fisher's & 38.541 & 0.000 \\
\hline - Apartment (independent) & 20 & 51.3 & 47 & 39.8 & Exact Test & & \\
\hline - 'Senior housing' & 10 & 25.6 & 8 & 6.8 & & & \\
\hline - Apartment in CHC\# & 7 & 17.9 & 3 & 2.5 & & & \\
\hline \multicolumn{8}{|l|}{ Changes in housing situation: } \\
\hline - No change & 10 & 30.3 & 96 & 93.2 & Fisher's & 57.990 & 0.000 \\
\hline - Bought rental dwelling & 0 & 0 & 2 & 1.9 & Exact Test & & \\
\hline - Moved to new construction & 12 & 36.4 & $* * * 1$ & 1.0 & & & \\
\hline - Moved to existing dwelling & 8 & 24.2 & $* * * 3$ & 2.9 & & & \\
\hline - Other & 3 & 9.1 & 1 & 1.0 & & & \\
\hline \multicolumn{8}{|l|}{$\begin{array}{l}\text { Experienced personal benefit }{ }^{\wedge} \text { of } \\
\text { restructuring? }\end{array}$} \\
\hline - Yes & 21 & 61.8 & 27 & 23.5 & Chi-Square & $\chi^{2}=17.72$ & 0.000 \\
\hline - No & 12 & 35.3 & 78 & 67.8 & & & \\
\hline - Don't know & 1 & 2.9 & 10 & 8.7 & & & \\
\hline \multicolumn{8}{|l|}{$\begin{array}{l}\text { Neighbourhood change in the past } \\
\text { few years: }\end{array}$} \\
\hline - Improved & 16 & 43.2 & 25 & 21.7 & Chi-Square & $\chi^{2}=11.10$ & 0.004 \\
\hline - Remained stable & 19 & 51.4 & 58 & 50.4 & & & \\
\hline - Declined & 2 & 5.4 & 32 & 27.8 & & & \\
\hline \multicolumn{8}{|c|}{$\begin{array}{l}\text { Is neighbourhood change an effect of } \\
\text { restructuring (RS)? }\end{array}$} \\
\hline - Completely due to the RS & 6 & 18.8 & 12 & 10.9 & Mann- & 1387.5 & 0.05 \\
\hline - Partly due to the RS & 13 & 40.6 & 35 & 31.8 & Whitney U & & \\
\hline - Hardly due to the RS & 6 & 18.8 & 21 & 19.1 & & & \\
\hline - Not at all related with RS & 7 & 21.9 & 42 & 38.2 & & & \\
\hline
\end{tabular}

Source: panel data extracted from surveys 2007 and 2012. Significant $p$-values $(p \leq 0.05)$ are printed boldly.

$\wedge$ 'Personal benefit': any benefit in the personal or housing situation which is directly linked to any restructuring intervention.

*** These are respondents who have ignored the routing in the original questionnaire; they have not moved in the years 2007-2012, but before this period; they nevertheless filled out the question about housing changes in this period of time.

\subsection{Changes in social support and loneliness}

As described in section 2, large-scale demolition and relocation may have disrupted socially supportive ties of older people, for whom a (strong) social network is crucial to mobilising practical and social support, and preventing social isolation and loneliness [9, 17, 18]. To measure support and loneliness over time, we combined similar indicators from the 2007 and 2012 surveys. Because the underlying studies have a partly different scope, we have only a limited number of five-point Likert scale items available for both years. With three items, exploratory or confirmatory factor analysis is not an option. Cronbach's $\alpha$ of the combined items is below the usual 0.7 cut-off, so the items cannot be combined into an index measure. Thus, we analyse each item separately (see Table 3 ). The items are:

1. In case of emergency, I can always call on someone close by for help.

2. I have to solve many problems myself as I get support from very few people.
3. I often feel lonely.

We deliberately refrained from making 'someone' or 'people' more specific, thus allowing for neighbourhoods, family members, friends or staff of care organisations to provide support.

For item 1 (emergency support) we found no significant difference between $t_{0}$ and $t_{1}$. This suggests that there is no change in the perceived emergency support of the panel members. Further analysis neither shows differences between $t_{0}$ and $t_{1}$ for stayers, and movers respectively.

For item 2 (lack of social support), we found that similar shares of respondents agree with the proposition on $t_{0}$ and $t_{1}$. Nevertheless, the Wilcoxon Sign Ranks Test indicates that there is actually a significant difference between $t_{0}$ and $t_{1}$. Closer inspection of Table 3 shows that the share of respondents who strongly disagree has decreased over time from 13 per cent in 2007 to 3 per cent 2012. Since the share of people disagreeing has decreased, it appears that the perceived level of social support has slightly decreased over time, showing a significant difference between 2007 
and 2012. The respondents who seem to have shifted between categories are predominantly stayers.

A similar pattern applies to item 3 (loneliness), with a decrease of 14 per cent strongly disagreeing with the statement. Thus, the level of loneliness seems to have slightly increased between 2007 and 2012. Again, the respondents who have shifted between categories are mostly stayers.

While the differences for items 2 and 3 are statistically significant, there is no evidence for a straightforward deterioration in the levels of social support and loneliness. Such a trend should have been reflected in higher shares of panel members who (strongly) agree with both negative statements. Considering this and the fact that the observed changes between $t_{0}$ and $t_{1}$ are associated with low numbers of respondents, applying multivariate modelling to the indicators of loneliness and social support is not possible.

Further bivariate analysis for each respondent group between $\mathrm{t}_{0}$ and $\mathrm{t}_{1}$ (see Table 4 ) reveals that the changes only apply to stayers in the same dwelling, for two of the three support variables. Among movers, the differences between $t_{0}$ and $t_{1}$ are not statistically significant for any of the three variables. Hence, respondents who were directly affected by urban restructuring (through a move) have not reported changes in their perceived levels of support and loneliness. In contrast, in the literature, this category is often supposed to be most negatively affected. The changes in the item scores are much more likely the result of 'natural losses' in people's networks due to their ageing, or other factors.

Table 3. Changes in social support and loneliness $2007-2012(\mathrm{n}=160)$

\begin{tabular}{|c|c|c|c|c|c|c|c|}
\hline \multirow[t]{2}{*}{ Indicator } & \multicolumn{2}{|c|}{$\mathbf{t}_{0}(\mathbf{2 0 0 7 )}$} & \multicolumn{2}{|c|}{$t_{1}(2012)$} & \multirow[t]{2}{*}{ Test type } & \multirow[t]{2}{*}{ Statistic } & \multirow[t]{2}{*}{ p-value } \\
\hline & $\mathbf{n}$ & $\%$ & $\mathbf{n}$ & $\%$ & & & \\
\hline \multicolumn{8}{|l|}{ Emergency support } \\
\hline - Strongly agree & 52 & 35.4 & 39 & 25.5 & Wilcoxon Sign & $Z=-0.984$ & 0.325 \\
\hline - Agree & 62 & 42.2 & 76 & 49.7 & Ranks Test & & \\
\hline - Neither agree nor disagree & 21 & 14.3 & 29 & 19.0 & & & \\
\hline - Disagree & 5 & 3.4 & 6 & 3.9 & & & \\
\hline - Strongly disagree & 7 & 4.8 & 3 & 2.0 & & & \\
\hline \multicolumn{8}{|l|}{ Lack of social support } \\
\hline - Strongly agree & 13 & 9.2 & 16 & 10.8 & Wilcoxon Sign & $Z=-2.711$ & 0.007 \\
\hline - Agree & 22 & 15.5 & 24 & 16.2 & Ranks Test & & \\
\hline - Neither agree nor disagree & 54 & 38.0 & 68 & 45.9 & & & \\
\hline - Disagree & 34 & 23.9 & 35 & 23.6 & & & \\
\hline - Strongly disagree & 19 & 13.4 & 5 & 3.4 & & & \\
\hline \multicolumn{8}{|l|}{ Feel often lonely } \\
\hline - Strongly agree & 4 & 3.0 & 6 & 4.0 & Wilcoxon Sign & $Z=-2.768$ & 0.006 \\
\hline - Agree & 12 & 8.9 & 12 & 8.0 & Ranks Test & & \\
\hline - Neither agree nor disagree & 13 & 9.6 & 31 & 20.7 & & & \\
\hline - Disagree & 56 & 41.5 & 67 & 44.7 & & & \\
\hline - Strongly disagree & 50 & 37.0 & 34 & 22.7 & & & \\
\hline
\end{tabular}

Source: panel data extracted from surveys 2007 and 2012. Significant $\mathrm{p}$-values $(\mathrm{p} \leq 0.05)$ are printed boldly.

Table 4. Changes in social support and loneliness 2007 - 2012, stayers versus movers

\begin{tabular}{|c|c|c|c|c|c|c|}
\hline \multirow[t]{2}{*}{ Indicator } & \multicolumn{3}{|c|}{ Movers $(n=39)$} & \multicolumn{3}{|c|}{ Stayers $(n=119)$} \\
\hline & Test Type & Statistic & p-value & Test Type & Statistic & $\mathrm{p}$-value \\
\hline Emergency support & Wilcoxon & $Z=-0.726$ & 0.469 & Wilcoxon & $Z=-1.253$ & 0.165 \\
\hline Lack of social support & Wilcoxon & $Z=-0.700$ & 0.484 & Wilcoxon & $Z=-2.964$ & 0.003 \\
\hline Feel often lonely & Wilcoxon & $Z=-1.324$ & 0.185 & Wilcoxon & $Z=-2.476$ & 0.013 \\
\hline
\end{tabular}

Source: panel data extracted from surveys 2007 and 2012. Significant $p$-values $(p \leq 0.05)$ are printed boldly. Wilcoxon: Wilcoxon Sign Rank Test. 


\section{Conclusions and Recommendations}

With rapidly ageing populations in European cities, there is a strong need for knowledge of 'ageing in place'. Many less affluent older people live in deprived urban neighbourhoods where low-quality housing, crime, disorder and social tensions have decreased the liveability of such areas $[7,13,22]$. In the Netherlands and beyond, such neighbourhoods have often been a target area of urban restructuring. There is still limited knowledge on the position and well-being of older people in the context of such interventions. This is not only because the literature on regeneration impacts usually encompasses the general population, but also because older people rarely feature in policies aimed at regenerating localities, despite the growth of the 'age-friendly approach' [12].

This paper contributes to the literature by moving beyond previous cross-sectional measurements of older people's opportunity to 'age in place' in restructuring neighbourhoods. Using a small but unique panel data set, the paper has explored changes in the housing situation, restructuring benefits, and perceived social support and loneliness, as these factors strongly assist older people's ability to live independently and to 'age in place' [20].

Contrary to the predominantly negative stance of the literature on urban regeneration areas, this paper has uncovered positive outcomes which can be attributed to restructuring. Especially residents who moved during the time frame of the panel reported an improved housing situation and positive neighbourhood change. Both outcomes are mostly related to movers' ability to access new housing in the same or another restructuring area in Hoogvliet. Prospective movers had various options, i.e. moving out of Hoogvliet or moving to another dwelling in the borough. The second option would appeal only to movers who were positive about the development or had other reasons to stay, e.g. the presence of important social ties. Hence, the 'buffer measures' in the restructuring plan [45], including the right to return, counselling, meeting opportunities and reduced rents of replacement housing, appear to have been effective in preventing negative impacts on older residents, including the stress related to the radical physical and population changes in their living environment $[13,32]$. This shows that, even in times of economic crisis (2008-2012) and welfare state retrenchment, a cleverly designed restructuring approach with high levels of support and attractive but affordable relocation opportunities can enable older people to benefit from what is generally considered as a stressful and destabilising situation in their living environment.

The exploratory analyses also showed that while panel members' perceived social support and loneliness have changed slightly over time, there is no evidence for a direct negative social impact of urban restructuring. The finding that (small) changes only occur among stayers is a bit counter-intuitive, as negative effects of urban restructuring are often associated with (forced) moves [35, $29,38,37,18]$. Here, the changes are much more likely the result of 'natural losses' in people's networks due to their ageing. The fact that we did not find any change in perceived support and loneliness among movers can be explained in multiple ways. First, the restructuring policy facilitated short distance moves, within the same neighbourhood or other neighbourhood in the borough, leaving intact crucial supportive ties. Second, several movers relocated into tailored senior housing or new co-housing communities. These outcomes reflect the active agency of older people who were able to choose among various relocation options or were involved in the creation of co-housing communities $[44,45]$.

Despite limitations of this study, our exploratory findings provide reason to be critical regarding straightforward claims about the disrupting impact of urban restructuring. Much research supporting such claims is conducted in the context of American public housing renewal, which is much 'harsher' than the Dutch approach in general and the approach in Hoogvliet in particular (see also [44]). In fact, the reported outcomes provide a counter-narrative to the American (and to a lesser extent, European) narrative that is predominantly rooted in a displacement discourse in the context of large-scale gentrification and negative experiences with urban restructuring [17, 18, 27-29, 35-37]. While it may not be possible to provide older residents of restructuring target areas in other developed countries with similar opportunities - particularly in light of cutbacks in funding on both sides of the Atlantic - this particular Dutch example supports a plea for more choices for residents in such areas [39]. Our findings have implications for urban restructuring policies in the USA, in particular 'Choice Neighborhoods', the successor of the well-known HOPE VI Program [48]. This program aims at improving housing and neighbourhoods by replacing distressed public housing or federally subsidized private housing with high-quality mixed-income housing, and improving neighbourhood conditions. Housing authorities need to clarify to residents more explicitly how they can benefit from restructuring, by providing a wider range of relocation options (on-site or other neighbourhoods) and continue to assist them in the housing choice process.

More general, housing associations on both sides of the Atlantic should provide opportunities for older people to continue familiar ways of interacting [31], also after urban restructuring. While our resources did not allow for in-depth analysis of the new co-housing communities in Hoogvliet, this particular intervention seems a promising avenue for ageing in place by older people who want to stick together. According to Hillcoat-Nalletamby and Ogg, 'a potential fear of vulnerability in living alone, coupled with a lack of engagement in communities of people, suggest that contemplating a move may be shaped more by a desire to 'attach' to people, than to remain in situ through 
preference for preserving any 'attachment to place' [41, $\mathrm{p}$. 1788-1789]. Further research should study such co-housing initiatives for older people as well as other bottom-up practices of urban restructuring that replace former top-down approaches. Obviously, larger panels and sample sizes would be necessary to validate the findings of the exploratory analyses reported in this paper. Further research should also take into account the role of rapidly changing policy contexts, such as the decreasing state support and decentralisation of homecare for older people $[4,49]$, that continue to affect the opportunities for ageing in place, also in regeneration areas.

\section{Acknowledgements}

The research leading to these results has received funding from Platform 31 in The Hague, as part of the program "Knowledge for Strong Cities" (Grant no. KKS2-2012-02), and also from Platform Corpovenista in Rotterdam, the housing associations Vestia and Woonbron, and the local authorities of Hoogvliet

\section{Appendix}

\begin{tabular}{ccc} 
Respondent characteristics (n=160) & & \\
\hline Indicator & $\mathbf{n}$ & \% \\
\hline Sex: & & \\
- Male & 107 & 66.9 \\
- Female & 53 & 33.1 \\
Age: & & \\
63 - 74 & 76 & 47.5 \\
$75-84$ & 71 & 44.4 \\
85 and older & 13 & 8.1 \\
Household composition: & & \\
- Single & 60 & 37.5 \\
- Couple without kids & 90 & 56.3 \\
- Couple with kids & 7 & 4.4 \\
- Other & 3 & 1.9 \\
Education: & & \\
- Primary school (or less) & 43 & 26.9 \\
- Lower secondary education & 60 & 37.5 \\
- Lower professional education & 23 & 14.4 \\
- Higher secondary education & 5 & 3.1 \\
- Higher professional education & 10 & 6.3 \\
- Other & 19 & 11.9 \\
Country of birth: & & \\
- The Netherlands & 144 & 90.0 \\
- Surinam & 6 & 3.8 \\
- Other & 7 & 4.4 \\
- Indonesia/Molukken & 3 & 1.9 \\
\hline & &
\end{tabular}

\section{REFERENCES}

[1] WHO. Global age-friendly cities: A guide, World Health Organization, Geneva, 2007.

[2] L. Gavrilov, P. Heuveline. Aging of Population: The Encyclopedia of Population, MacMillan, New York, 2003.

[3] A. Tinker, J. Ginn, E. Ribe. Assisted Living Platform - The Long Term Care Revolution: A study of innovatory models to support older people with disabilities in the Netherlands. Housing Learning and Improvement Network (LIN) Case study 37, London, 2013.

[4] T. Dijkhoff. The Dutch Social Support Act in the shadow of the decentralization dream, Journal of Social Welfare and Family Law, Vol. 36, No. 3, 276-294.

[5] R. Gilroy. Places that support human flourishing: lessons from later life, Planning Theory \& Practice, Vol. 9, No. 2, 145-163.

[6] J. Wiles, A. Leibing, N. Guberman, J. Reeve, R. Allen. The meaning of "aging in place" to older people, Gerontologist, Vol. 52, No. 3, 357-366.

[7] A.E. Smith. Ageing in urban neighbourhoods: Place attachment and social exclusion, Policy Press, Bristol, 2009.

[8] A. Davies, A. James. Geographies of ageing: Social processes and the spatial unevenness of population ageing, Ashgate Publishing Ltd, London, 2011.

[9] P. J. Gardner. Natural neighborhood networks - important social networks in the lives of older adults aging in place, Journal of Aging Studies, Vol. 25, No. 3, 263-271.

[10] C.W. Lui, J.A. Everingham, J. Warburton, M. Cuthill, H. Bartlett. What makes a community age-friendly: A review of international literature, Australasian Journal on Ageing, Vol. 28, No. 3, 116-121.

[11] C. Phillipson. Developing age-friendly communities: New approaches to growing old in urban environments, In: J.A. Settersten (Ed.), Handbook of Sociology of Aging, Springer, New York, 279-293, 2011.

[12] T. Buffel, C. Phillipson, T. Scharf. Ageing in urban environments: Developing 'age-friendly' cities, Critical Social Policy, Vol. 32, No. 4, 597-617.

[13] M. van Der Meer, J.D. Fortuijn, F. Thissen. Vulnerability and environmental stress of older adults in deprived neighbourhoods in the Netherlands, Tijdschrift voor Economische en Sociale Geografie, Vol. 99, No. 1, 53-64.

[14] I. Wilson. Outcomes for 'stayers' in urban regeneration areas: the New Deal for Communities Programme in England, Urban Research \& Practice, Vol. 6, No. 2, 174-193.

[15] M. Egan, S. Katikireddi, A. Kearns, C. Tannahill, M. Kalacs, L. Bond. Health effects of neighborhood demolition and housing improvement: a prospective controlled study of two natural experiments in urban renewal, American Journal of Public Health, Vol. 103, No. 6, e47-e53.

[16] D. Phillips, O. Siu, A. Yeh, K. Cheng. Ageing and the urban environment. In: D. Andrews (Ed.), Ageing and place: Perspectives, Policy, Practice. Routledge, New York, 147-163, 2005. 
[17] L.C. Manzo, R.G. Kleit, D. Couch. "Moving Three Times Is Like Having Your House on Fire Once": The Experience of Place and Impending Displacement among Public Housing Residents, Urban Studies, Vol. 45, No. 9, 1855-1878.

[18] E. G. Goetz. Desegregation in 3D: displacement, dispersal and development in American public housing, Housing Studies, Vol. 25, No. 2, 137-158.

[19] T. Scharf, J. de Jong Gierveld. Loneliness in urban neighbourhoods: an Anglo-Dutch comparison, European Journal of Ageing, Vol. 5, No. 2, 103-115.

[20] J. Sixsmith, A. Sixsmith, A. Fänge, D. Naumann, C. Kucsera, S. Tomsone, R. Woolrych. Healthy ageing and home: The perspectives of very old people in five European countries, Social Science \& Medicine, Vol. 106, 1-9.

[21] F. Ziegler. "You have to engage with life, or life will go away": An intersectional life course analysis of older women's social participation in a disadvantaged urban area, Geoforum, Vol. 43, No. 6, 1296-1305.

[22] R. Kleinhans, L. Veldboer, W. Doff, S. Jansen, M. van Ham. Terugblikken en vooruitkijken in Hoogvliet: 15 jaar stedelijke vernieuwing en de effecten op wonen, leefbaarheid en sociale mobiliteit [Looking Back and Forward in Hoogvliet. 15 Years of Urban Restructuring and Implications for Housing, Liveability and Social Mobility], Delft University of Technology, Faculty of Architecture and the Built Environment, Delft, 2014.

[23] R. Atkinson, H. Thomson, A. Kearns, M. Petticrew. Giving urban policy its' medical': assessing the place of health in area-based regeneration, Policy \& Politics, Vol. 34, No. 1, $5-26$.

[24] H. Thomson, R. Atkinson, M. Petticrew, A. Kearns. Do urban regeneration programmes improve public health and reduce health inequalities? A synthesis of the evidence from UK policy and practice (1980-2004), Journal of Epidemiology and Community Health, Vol. 60, No. 2, 108-115.

[25] H. Thomson, S. Thomas, E. Sellstrom, M. Petticrew. The health impacts of housing improvement: a systematic review of intervention studies from 1887 to 2007, American Journal of Public Health, Vol. 99, No. 3, 681-692.

[26] R. A. Lindberg, E.D. Shenassa, D. Acevedo-Garcia, S.J. Popkin, A. Villaveces, R.L. Morley. Housing interventions at the neighborhood level and health: a review of the evidence, Journal of Public Health Management and Practice, Vol. 16, No. 5, S44-S52.

[27] G. Davidson, D. McGuinness, P. Greenhalgh, P. Braidford, F. Robinson. 'It'll get worse before it gets better': Local experiences of living in a regeneration area, Journal of Urban Regeneration and Renewal, Vol. 7, No. 1, 55-66.

[28] A. Kearns, P. Mason. Defining and measuring displacement: is relocation from restructured neighbourhoods always unwelcome and disruptive? Housing Studies, Vol. 28, No. 2, 177-204.

[29] M. Ekström. Elderly people's experiences of housing renewal and forced relocation: Social theories and contextual analysis in explanations of emotional experiences, Housing Studies, Vol. 9, No. 3, 369-391.

[30] L.C. Manzo. On uncertain ground: being at home in the context of public housing redevelopment, International Journal of Housing Policy, Vol. 14, No. 4, 389-410.

[31] D. Lager, B, van Hoven, P. Huigen. Dealing with change in old age: Negotiating working-class belonging in a neighbourhood in the process of urban renewal in the Netherlands, Geoforum, Vol. 50, 54-61.

[32] G. Rowles, J. Watkins. History, Habit, Heart, and Hearth: On Making Spaces into Places, In: K. Warner Schaie, H. Wahl, H. Mollenkopf, F. Oswald (Eds.) Aging Independently: Living Arrangements and Mobility, Springer Publishing Company, New York, 77-96, 2003.

[33] S. Peace, C. Holland, L. Kellaher. 'Option recognition' in later life: variations in ageing in place, Ageing and Society, Vol. 31, No. 5, 734-757.

[34] P. Jones, J. Evans. Rescue Geography: Place Making, Affect and Regeneration, Urban Studies, Vol. 49, No. 11, 2315-2330.

[35] M. Fried. Grieving for a lost home: psychological costs of relocation, In: L. Duhl (Ed.), The Urban Condition, Basic Books, New York, 151-171, 1963.

[36] T. Allen. Housing Renewal,Doesn't it Make You Sick? Housing Studies, Vol. 15, No. 3, 443-461.

[37] S. Greenbaum, W. Hathaway, C, Rodriguez, A. Spalding, B. Ward. Deconcentration and Social Capital: Contradictions of a Poverty Alleviation Policy, Journal of Poverty, Vol. 12, No. 2, 201-228

[38] R. Kleinhans. Displaced but still moving upwards in the housing career? Implications of forced residential relocation in the Netherlands, Housing Studies, Vol. 18, No. $4,473-499$

[39] H. Posthumus, G. Bolt, R. van Kempen, R. Victims or victors? The effects of forced relocations on housing satisfaction in Dutch cities, Journal of Urban Affairs, Vol. 36, No. 1, 13-32.

[40] H. van Dijk, J. Cramm, K. van Exel, A. Nieboer. The ideal neighbourhood for ageing in place as perceived by frail and non-frail community-dwelling older people, Ageing \& Society, Vol. 35, No. 8, 1771-1795.

[41] S. Hillcoat-Nalletamby, J. Ogg. Moving beyond 'ageing in place': older people's dislikes about their home and neighbourhood environments as a motive for wishing to move, Ageing \& Society, Vol. 34, No. 10, 1771-1796.

[42] I. Hardill, S. Baines. Active Citizenship in Later Life: Older Volunteers in a Deprived Community in England, the Professional Geographer, Vol. 61, No. 1, 36-45.

[43] A. Kearns, E. Whitley, C. Tannahill, A, Ellaway. Loneliness, social relations and health and well-being in deprived communities, Psychology, Health \& Medicine, Vol. 20, No. 3, 332-344.

[44] ODPM. UK Presidency EU ministerial informal on sustainable communities: European evidence review papers. Office of the Deputy Prime Minister, London, 2006.

[45] Deelgemeente Hoogvliet. Hoogvliet eigenzinnige stad. Investeringsplan Strategische Wijkaanpak Hoogvliet-Noord en Maasranden [Hoogvliet Self-Willed City. Investment Plan Strategic Neighbourhood Approach 
and Maasranden]. Borough of Hoogvliet, Rotterdam, 1999.

[46] L. Veldboer, J.W. Duyvendak, R. Kleinhans, N. Boonstra. In beweging brengen en richting geven. Herstructurering en sociale stijging in Hoogvliet [Setting in Motion and Providing Direction. Urban Restructuring and Upward Social Mobility in Hoogvliet]. Borough of Hoogvliet, Rotterdam, 2007.

[47] H. Posthumus, R. Kleinhans, G. Bolt. Bijwerkingen van herstructureringsoperaties. Verhuizingen, waterbedeffecten en veranderingen in de woningvoorraad [Side Effects of
Urban Restructuring Interventions. Residential Mobility, Spillover Effects and Changes in the Housing Stock]. Eburon, Delft, 2012.

[48] U.S. Department of Housing and Urban Development (HUD), Choice Neighborhoods, Online available from https://portal.hud.gov/hudportal/HUD?src=/program_offic es/public_indian_housing/programs/ph/cn.

[49] S. Dobner, S. Musterd, J.D. Fortuijn. 'Ageing in place': experiences of older adults in Amsterdam and Portland, GeoJournal, Vol. 81, No. 2, 197-209. 